\title{
Dairy Farmers' Risk Perception and Risk Management in China - Evidence from Hebei Province and Inner Mongolia
}

\author{
Hui Zhou ${ }^{1,2)}$, Teruaki Nanseki*3) and Shigeyoshi Takeuchi ${ }^{3)}$ \\ 1) Graduate School of Bioresource and Bioenvironmental Science, Kyushu University, Japan \\ 2) Institute of Agricultural Economics and Development, Chinese Academy of Agricultural Science, China \\ 3) Faculty of Agriculture, Kyushu University, 6-10-1 Hakozaki, Higashi, Fukuoka 812-8581, Japan
}

\begin{abstract}
This paper outlines the main source of risks and the main risk management strategies to dairy farmers in China. Dairy is an industry with big potential in China, both consumption and production increase dramatically in recent years and now China is the third biggest milk producer in the world, right after USA and India (Food Agriculture Organization of United Nations (FAO) (2008) FAOSTAT Agriculture Database, accessed November 2008, available at $<$ http://faostat.fao.org/site/339/default.aspx $>$ ). As a way to increase farmers' income and improve people's diet structure, the Chinese government encourages farmers to raise cows and produce milk. However, risks in both food and agriculture including food contamination by chemical, animal diseases and price variability in China may cause big damage for both dairy farmers and consumers. To understand farmers' perception and response to risk is important to policy makers as well as economists. And helping farmers to manage different kind of risk is a way to reduce farmers' losses. In this study, dairy farmers' risk perception and risk management strategies are mainly examined. Farmers' risk perception and risk management strategies were studied by using Principal Component Analysis (PCA). The survey was carried out in Hebei Province and Inner Mongolia in April and June, 2010. 168 samples are available for this study. According to the results, we found that price and animal diseases such as foot and mouth disease post large threats to dairy farmers. In addition, producing at the lowest cost and preventing livestock disease are the most useful risk management strategies for dairy farmers. Farmer corporation association and agricultural insurance becomes a way to help farmers to manage risk in many crops and some other animal products, but such acts are not so popular to dairy farmers in China yet. To improve these strategies is useful for dairy farmers as well and might help them to avoid many risks and reduce losses.
\end{abstract}

\section{Keywords}

risk perception, risk management, principle component analysis, dairy farmers

\section{Introduction}

The past decades, Asian people were changing their diets; they tend to have less rice while taking more milk as well as meat and eggs. This situation not has just happened in China but also in other countries such as Japan and Korea. Dairy is an industry with big potential in China, both consumption and production increase dramatically in recent years and now China is the third biggest milk producer in the world, right after USA and India (FAO 2008). As a way to increase farmers' income and to improve the

* Corresponding Author

E-mail: nanseki@agr.kyushu-u.ac.jp people' diet structure, the Chinese government encourages farmers to raise more cows and produce milk.

However, risks in both food and agriculture including food contamination by chemical, animal diseases and price variability in China may give both dairy farmers and consumers big damages. Dairy farmers were negatively affected by these risks the most, as they belong to the weakest part of the whole milk supply chain. It is important for policy makers to understand farmers' perception and their response to the risk in order to help dairy farmers to reduce their losses.

\section{Risk management and information management}

Agricultural management is constructed by several parts, 


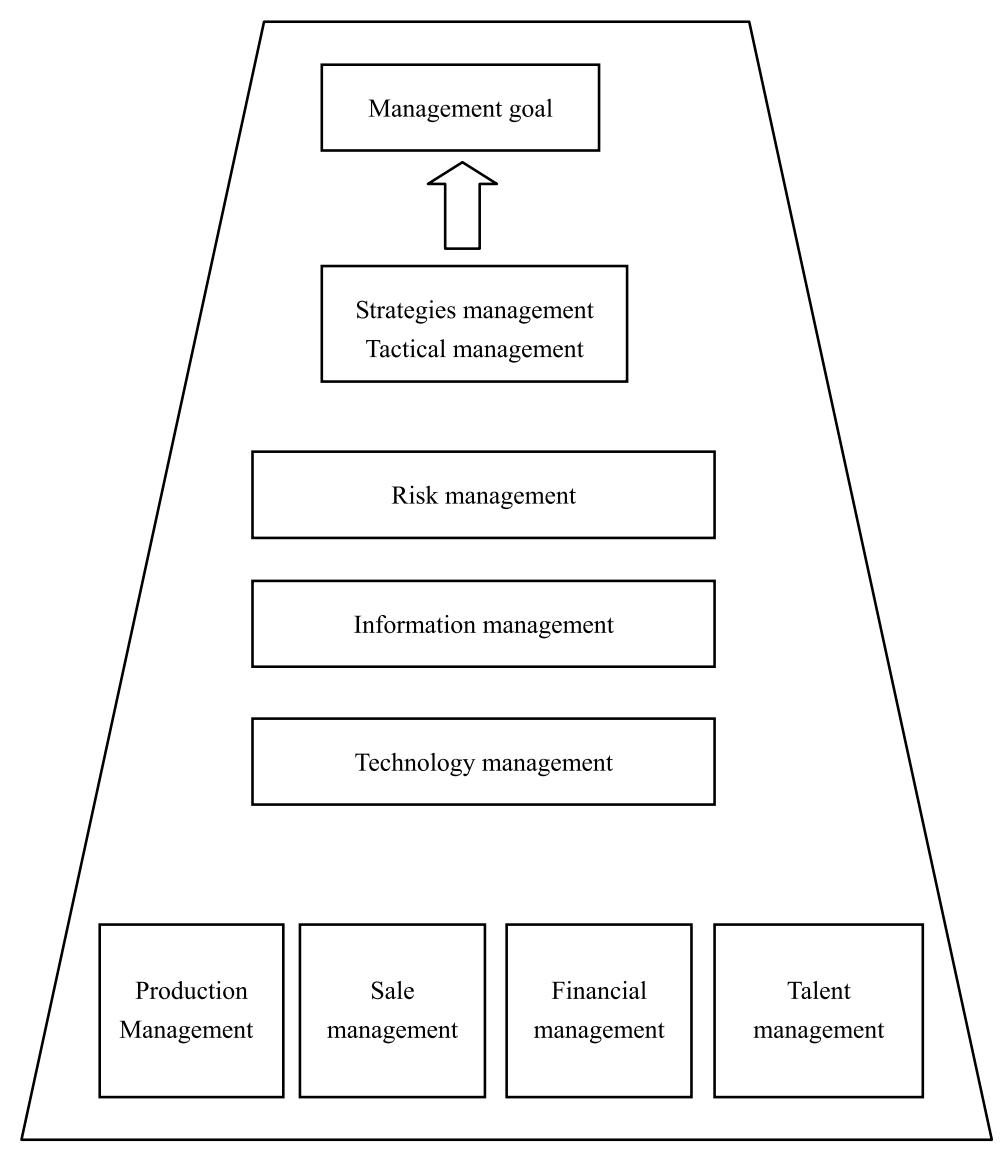

Fig. 1 The full picture of management in agriculture Source: Nanseki (2011), p. 39

including risk management, information management, technology management and others. To understand and estimate the potential risk quickly and properly is very important. This is a first step of risk management. Besides, to collect, process, provide and analyze information effectively is also necessary in risk management as well as in agricultural management. This is a first step of information management. In information management, new technologies such as Information and Communication Technology (ICT) has been increasingly used on management strategies (Fig. 1, Nanseki 2011).

Recent years, farmers made their both short-term and longterm decisions based on many various kinds of information. When farmers face any risk or uncertainty, they need information to estimate the risk, make proper decision, and manage the risk. That is how the risk management, information management and whole agricultural management connect with each other.

\section{Literature review}

Agriculture is inherently risky. Farm outputs depend on weather and biological processes over which producers have little control, and competition in domestic as well as international markets exposes agricultural producers to unanticipated price fluctuations (Fleisher 1990). However, some of the risk in livestock sector is different from crop sector. Our paper mainly focuses on dairy farmers' risk perception and risk management strategies.

There are several papers about farmers' risk perception. Economic Research Service (ERS 1997) has summarized USA studies. In US, dairy farmers were most concerned about commodity price risk, production risk, and changes in government laws and regulations. Dairy farmers in Arizona perceived the costs of operating inputs to be the greatest source of risk (Wilson et al. 1988). Dairy farmers in New Zealand viewed price risk and rainfall variability as highest risk (Martin 1996). Meuwissen et al. (2001) found that Dutch livestock farmers considered price and production risks to be most important. In Japan, the biggest and the sometime happened risks to livestock farmers are decrease of production by animal death and decrease of quality by equipment breakdown (Nanseki 2011).

ERS (1997) also found that keeping cash on hand was the chief risk management strategy for every farm size, for every commodity specialty, and in every region studied; use of derivative and insurance markets was also considered important. Maintaining animal health was viewed as the most effective strategy. The researches in Dutch found that producing at lowest possible costs and insurance were the most important risk management strategies (Meuwissen et al. 2001). A study among Finnish farmers 
found changes in agricultural policy as the most important risk factor, while maintaining adequate liquidity and solidity was the most important management response (Sonkkila 2002).

In China, there are several risks that the whole dairy industry faces. Food safety problem is considered as one of the biggest risk for dairy industry (Wu 2009, Chen 2009). Lack of completed law and regulation system, the breed of cow is not pure and low yield is considered as important risk for the whole industry ( $\mathrm{Wu} 2009)$.

However, in China, most papers in this field focused on the macro level-from the point of view of the whole industry. And there are very few studies pay attention to dairy farmers' perception at this moment. Therefore this research focuses on discovering dairy farmers' perception of risk and their risk management strategies in China.

\section{Research objectives}

In this research, dairy farmers' perception of risk and their point of view on risk management strategies are studied. Risk is uncertainty that affects an individual's welfare, and is often associated with adversity and loss (ERS 1997). Giving response to risky situations, farmers should be involved in risk management, making choices among alternatives so as to reduce the effects of the risks.

The main research objectives are:

To examine the dairy farmers' perception of risk;

To examine the risk management strategies of dairy farmers.

\section{Data and Method}

\section{Questionnaire and analysis technique}

In this study, survey has been conducted to sample farmers by asking their most worried risks and their risk management strategies to cope with such risks. There are a number of sources of risk and risk management strategies listed on questionnaire. Based on previous studies (Wilson et al. 1988, ERS 1997, Meuwissen et al. 2001, Flaten et al. 2005), 22 sources of risk and 18 risk management strategies were given in the questionnaire at first. However, after consulting with experts and considering the current situation in China, finally, there are 19 sources of risk and 15 risk management strategies were selected in the questionnaire of this study (Tables 1 and 2). In China, farmers do not need to pay tax since 2006, so that all the risks about tax payment are deleted. In the survey, most farmers are small scale farmers, and there are no organic farmers, all the risks related to organic dairy farmers are deleted.

To understand which risk and risk management strategies has been put more weight on, the 5 level of likert scale questions are used. Dairy farmers are requested to judge and label different levels of each risk and risk management strategies. Level 1 stands for the least importance and level 5 stands for the most importance.
Table 1 Sources of risk of dairy farmers

\begin{tabular}{|c|c|c|c|c|c|}
\hline Category & \multicolumn{5}{|c|}{ Level } \\
\hline 1. Changes in consumers preferences & 1 & 2 & 3 & 4 & 5 \\
\hline 2. Production diseases such as mastitis & 1 & 2 & 3 & 4 & 5 \\
\hline $\begin{array}{l}\text { 3. Domestic epidemic animal diseases such as } \\
\text { Para tuberculosis }\end{array}$ & 1 & 2 & 3 & 4 & 5 \\
\hline $\begin{array}{l}\text { 4. Non-domestic epidemic animal diseases such } \\
\text { as foot and mouth disease }\end{array}$ & 1 & 2 & 3 & 4 & 5 \\
\hline $\begin{array}{l}\text { 5. Misuse in veterinary drugs and veterinary } \\
\text { drug residues }\end{array}$ & 1 & 2 & 3 & 4 & 5 \\
\hline 6. Related food safety issues happened & 1 & 2 & 3 & 4 & 5 \\
\hline 7. Food safety news in media & 1 & 2 & 3 & 4 & 5 \\
\hline 8. Milk yield variability & 1 & 2 & 3 & 4 & 5 \\
\hline 9. Milk price variability & 1 & 2 & 3 & 4 & 5 \\
\hline 10. Corn yield variability & 1 & 2 & 3 & 4 & 5 \\
\hline 11. Corn price variability & 1 & 2 & 3 & 4 & 5 \\
\hline 12. Crop yield variability & 1 & 2 & 3 & 4 & 5 \\
\hline 13. Crop price variability & 1 & 2 & 3 & 4 & 5 \\
\hline 14. Costs of operating inputs & 1 & 2 & 3 & 4 & 5 \\
\hline 15. Changes in technology & 1 & 2 & 3 & 4 & 5 \\
\hline 16. Changes in government support payments & 1 & 2 & 3 & 4 & 5 \\
\hline 17. Health problems among family members & 1 & 2 & 3 & 4 & 5 \\
\hline 18. Hard to get load & 1 & 2 & 3 & 4 & 5 \\
\hline 19. Fire damage, flood, dry, or other damage & 1 & 2 & 3 & 4 & 5 \\
\hline
\end{tabular}

Note: $1=$ Least Important, $5=$ Most Important

Table 2 Risk management strategies of dairy farmers

\begin{tabular}{|c|c|c|c|c|c|}
\hline Category & \multicolumn{5}{|c|}{ Level } \\
\hline 1. Production contracts & 1 & 2 & 3 & 4 & 5 \\
\hline 2. Liquidity-keep cash in hand & 1 & 2 & 3 & 4 & 5 \\
\hline $\begin{array}{l}\text { 3. Using consultants service or consultant } \\
\text { extension workers }\end{array}$ & 1 & 2 & 3 & 4 & 5 \\
\hline 4. Joining the extension training program & 1 & 2 & 3 & 4 & 5 \\
\hline $\begin{array}{l}\text { 5. Asset flexibility-farm building with multiple } \\
\text { uses }\end{array}$ & 1 & 2 & 3 & 4 & 5 \\
\hline $\begin{array}{l}\text { 6. Keeping fixed costs low-hire machinery rather } \\
\text { than purchase it }\end{array}$ & 1 & 2 & 3 & 4 & 5 \\
\hline $\begin{array}{l}\text { 7. Shared ownership of equipment, joint } \\
\text { operations }\end{array}$ & 1 & 2 & 3 & 4 & 5 \\
\hline 8. Off farm work & 1 & 2 & 3 & 4 & 5 \\
\hline 9. Collecting information & 1 & 2 & 3 & 4 & 5 \\
\hline 10. Risk reducing technologies & 1 & 2 & 3 & 4 & 5 \\
\hline 11. Joining the farmers corporation & 1 & 2 & 3 & 4 & 5 \\
\hline 12. Producing at lowest possible cost & 1 & 2 & 3 & 4 & 5 \\
\hline 13. Prevent/ reduce livestock diseases & 1 & 2 & 3 & 4 & 5 \\
\hline 14. Buying agricultural insurance & 1 & 2 & 3 & 4 & 5 \\
\hline $\begin{array}{l}\text { 15. Kill the cows or sell the cows, quit the } \\
\text { business }\end{array}$ & 1 & 2 & 3 & 4 & 5 \\
\hline
\end{tabular}

Note: $1=$ Least Important, 5=Most Important

Note: Keep cash in hand is considered as one of the risk management strategies can handle with all kinds of risk and fits for all size of farms.

Produce at the lowest cost means dairy farmers will do everything that could help them to keep the variable cost low, such as use the least amount of feed.

Prevent and reduce livestock disease here means during the dairy feeding, farmers add some medicine into feed to avoid certain diseases; using human medicine instead of animal medicine and so on. 
Table 3 Socio-feature of sample farmers

\begin{tabular}{|c|c|c|c|c|c|}
\hline \multicolumn{3}{|c|}{ Category } & \multicolumn{3}{|c|}{ Category } \\
\hline \multirow{2}{*}{ Gender } & Male & $69 \%$ & \multirow{5}{*}{ Education } & Illiterate & $13.1 \%$ \\
\hline & Female & $31 \%$ & & Primary School & $26.2 \%$ \\
\hline \multirow{2}{*}{\multicolumn{2}{|c|}{$\begin{array}{l}\text { Average yield of } \\
\text { each cattle }(\mathrm{kg})\end{array}$}} & \multirow{2}{*}{3952} & & Junior High school & $41.4 \%$ \\
\hline & & & & Senior High school & $16.5 \%$ \\
\hline Average & & 42.2 & & College & $2.8 \%$ \\
\hline
\end{tabular}

Source: self-survey 2010

Samples $=168$

Farmers' risk perception and risk management strategies were studied by descriptive analyses. When the number of variable is large, a multivariate analysis technique such as Principle Component Analysis (PCA) is effective to reduce its dimensionality. PCA is one of multivariate technique that analyzes a data table in which observations are described by several inter-correlated quantitative dependent variables (Abdi and Williams 2010). Its goal is to extract the important information from the data, to represent it as a set of new orthogonal variables called principal components, and to display the pattern of similarity of the observations and of the variables as points in maps. In this research, therefore PCA is used to analyze the survey data. PCA is suitable to extract the principal risk and strategy from many risks and risk management strategies. To reduce the dimensionality of the variables, PCA is a powerful tool to do such work and without losing much information. Besides, this method was often used in many similar researches before. So that PCA considered as is a proper way to analyze data and is adopted in this case. All analyses including PCA were carried out by using SPSS 13.0 (SPSS Inc. 2007) for Windows.

\section{Study site and respondent's attribute}

The data for this study comes from a general survey in North Part of China. The survey was conducted by Institute of Agricultural Economics and Development, Chinese Agricultural Academy of which the first author is a research staff. The field survey was carried out in Inner Mongolia and Hebei Province in April and June 2010 respectively. 20 villages were visited in Inner Mongolia and 23 villages were visited in Hebei Province. In each village, 15 households were visited randomly. 623 samples were collected in this survey including all kinds of farmers. Only 168 samples were dairy farmers and available for analysis in this study.

Both Hebei Province and Inner Mongolia are the main graingrowing area and important milk production areas in China. Borders of two provinces are next adjacent to each other and located in North Part of China. Inner Mongolia is the largest milk producer in China and Hebei Province is the third biggest milk producer in China.
In this survey, most respondents are male, and nearly $80 \%$ of the respondents get their education less than 9 years (Table 3 ). Most of the dairy farmers own less than 20 cattle, more than half of the dairy farmers only own around 10 cattle in each household. Meanwhile most dairy farmers have their own lands to grow corn which is used as main feed for cows. Compared to privileged countries such as USA and some European countries, the yearly average yield of each cow is not desirable, which is only around $4,000 \mathrm{~kg}$. In USA, a pure Holstein cow can produce around $10,000 \mathrm{~kg}$ milk per year. This is because the cow in this area is pure Holstein mixed with local cattle so that the yield of second generation of mixed Holstein cow is lower than the pure Holstein cow.

\section{Result and Discussion}

\section{Farmers' perception of risk}

Table 4 shows the dairy farmers' perception of risk in both Inner Mongolia and Hebei Province. The table shows that, on average, the highest scores are given to variability of milk price in both places. In general, price and production risks are considered as the biggest risk. In Inner Mongolia, milk price variability, nondomestic epidemic animal diseases such as foot and mouth disease and corn price variability are considered as the three biggest risks. However, the situation in Hebei Province is slightly different. Besides milk price variability and non-domestic epidemic animal diseases such as foot and mouth disease, other food safety issues is also considered as one of the most important risk for dairy farmers. In 2008, the milk powder scandal is found in Hebei province at first, and the scandal finally made the local dairy company bankrupt. And it becomes difficult for some local farmers to sell fresh milk. This shows that experience of milk and food safety issue in past still negatively affects dairy farmers in Hebei Province.

These results in China are similar with related researches carried out in some other countries, such as price variability in products, animal diseases such as foot and mouth disease and others. However, in those developed countries, mastitis is not such serious disease to cows, but in China, it is still a big problem which disturbs Chinese dairy farmers. This is because in most developed countries, a better and more modern way is used in raising cows, while in China old-fashioned and traditional way is still used by the farmers which make this kind of production disease easier to happen. For example, in most developed countries, the Total Mixed Ration (TMR) technical is used to raise cow, however, in China, those small scale dairy farmers even have no idea about TMR. Inappropriate ways of raising cows may cause mastitis and other diseases. In most developed countries, machines are totally used to milk the cows. But in China, some farmers still use hands to milk cows. Besides, the disinfection technique on the cows in 
Table 4 Mean score and rank for source of risk

\begin{tabular}{|c|c|c|c|c|c|c|}
\hline \multirow{2}{*}{ Category } & \multicolumn{2}{|c|}{ All the data } & \multicolumn{2}{|c|}{ Hebei Province } & \multicolumn{2}{|c|}{ Inner Mongolia } \\
\hline & Mean & Rank & Mean & Rank & Mean & Rank \\
\hline Milk price variability & 4.86 & 1 & 4.89 & 1 & 4.82 & 1 \\
\hline Food safety issue news in media & 4.47 & 2 & 4.78 & 2 & 4.01 & 4 \\
\hline Non-domestic epidemic animal diseases such as foot and mouth disease & 4.42 & 3 & 4.31 & 4 & 4.57 & 2 \\
\hline Related food safety issues happened & 4.41 & 4 & 4.74 & 3 & 3.93 & 6 \\
\hline Corn price variability & 4.15 & 5 & 4.19 & 5 & 4.09 & 3 \\
\hline Production diseases such as mastitis & 3.83 & 6 & 3.82 & 7 & 3.84 & 7 \\
\hline Misuse in veterinary drugs and veterinary drug residues & 3.70 & 7 & 3.67 & 9 & 3.74 & 8 \\
\hline Crop price variability & 3.67 & 8 & 4.04 & 6 & 3.22 & 11 \\
\hline Corn yield variability & 3.65 & 9 & 3.41 & 10 & 3.99 & 5 \\
\hline Crop yield variability & 3.31 & 10 & 3.37 & 11 & 3.12 & 13 \\
\hline Domestic epidemic animal diseases such as Para tuberculosis & 3.30 & 11 & 3.11 & 12 & 3.59 & 9 \\
\hline Fire damage, flood, dry, or other damage & 3.23 & 12 & 3.76 & 8 & 2.46 & 18 \\
\hline Health problems among family members & 3.21 & 13 & 3.07 & 13 & 3.41 & 10 \\
\hline Milk yield variability & 3.10 & 14 & 3.06 & 14 & 3.16 & 12 \\
\hline Costs of operating inputs & 2.62 & 15 & 2.38 & 15 & 2.97 & 15 \\
\hline Changes in government support payments & 2.58 & 16 & 2.31 & 16 & 2.99 & 14 \\
\hline Changes in technology & 2.38 & 17 & 2.28 & 17 & 2.53 & 16 \\
\hline Changes in consumers preferences & 2.36 & 18 & 2.26 & 18 & 2.51 & 17 \\
\hline Hard to get load & 1.73 & 19 & 1.61 & 19 & 1.91 & 19 \\
\hline
\end{tabular}

Source: self-calculation based on survey 2010

Note: the order of risk is based on mean score of each one (Column 2).

Table 5 Varimax rotated factor loading for source of risk

\begin{tabular}{|c|c|c|c|c|c|c|c|}
\hline \multirow[b]{2}{*}{ Category } & \multicolumn{7}{|c|}{ Component } \\
\hline & $\begin{array}{l}\text { Factor } 1 \\
\text { Production }\end{array}$ & $\begin{array}{l}\text { Factor } 2 \\
\text { Institutional }\end{array}$ & $\begin{array}{c}\text { Factor } 3 \\
\text { Animal disease }\end{array}$ & $\begin{array}{l}\text { Factor } 4 \\
\text { Input market }\end{array}$ & $\begin{array}{c}\text { Factor } 5 \\
\text { Milk contamination }\end{array}$ & $\begin{array}{c}\text { Factor } 6 \\
\text { Personal }\end{array}$ & $\begin{array}{c}\text { Factor } 7 \\
\text { Output market }\end{array}$ \\
\hline Crop yield variability & .834 & .286 & -.019 & .102 & -.029 & -.004 & -.012 \\
\hline Costs of operating inputs & .810 & .347 & -.088 & .218 & .247 & .061 & -.009 \\
\hline Fire damage, flood, dry, or other damage & -.796 & .057 & -.029 & -.055 & -.118 & -.151 & .008 \\
\hline Corn yield variability & .715 & .260 & -.182 & -.090 & -.083 & -.139 & -.426 \\
\hline Related food safety issues happened & -.507 & .208 & .436 & .173 & -.426 & -.218 & .123 \\
\hline Changes in government support payments & -.112 & .888 & .060 & -.218 & .043 & -.086 & -.038 \\
\hline Changes in technology & .406 & .578 & .362 & .032 & -.079 & .400 & -.033 \\
\hline Domestic epidemic diseases such as Para tuberculosis & .080 & .101 & .866 & -.078 & .135 & -.058 & -.094 \\
\hline Misuse in veterinary drugs and veterinary residues & -.014 & -.212 & .800 & .276 & .140 & .167 & .068 \\
\hline $\begin{array}{l}\text { Non-domestic epidemic animal diseases such as } \\
\text { foot and mouth disease }\end{array}$ & .297 & .242 & -.725 & .008 & -.181 & .223 & -.179 \\
\hline Production diseases such as mastitis & .012 & -.017 & 644 & -.242 & .040 & -.146 & -.118 \\
\hline Corn price variability & .186 & .000 & .084 & .785 & .059 & -.243 & .197 \\
\hline Crop price variability & -.396 & .325 & .012 & .724 & -.220 & -.061 & .034 \\
\hline Hard to get load & .133 & .372 & .298 & -.559 & .373 & .153 & .332 \\
\hline Food safety issue news in media & -.479 & .176 & .443 & .111 & -.553 & -.092 & .149 \\
\hline Health problems among family members & .044 & .061 & -.482 & -.092 & .147 & .692 & .210 \\
\hline Changes in consumers preferences & .061 & -.161 & .096 & -.209 & -.063 & -.129 & .799 \\
\hline Milk yield variability & .093 & .263 & .171 & .321 & .414 & .087 & -.565 \\
\hline Milk price variability & -.133 & .225 & -.031 & .247 & -.087 & -.014 & .753 \\
\hline Cumulative percent of the variance explained (\%) & 24.329 & 37.776 & 48.647 & 57.693 & 65.344 & 71.933 & 77.419 \\
\hline
\end{tabular}

Source: self-calculation based on survey 2010

Extraction Method: Principal Component Analysis. Rotation Method: Varimax with Kaiser Normalization. Loadings of larger than $|0.5|$ are in bold. 
Table 6 Mean score and rank for the risk management strategies

\begin{tabular}{|c|c|c|c|c|c|c|}
\hline \multirow{2}{*}{ Category } & \multicolumn{2}{|c|}{ All data } & \multicolumn{2}{|c|}{ Hebei Province } & \multicolumn{2}{|c|}{ Inner Monglia } \\
\hline & Mean & Rank & Mean & Rank & Mean & Rank \\
\hline Producing at the lowest cost & 4.76 & 1 & 4.81 & 1 & 4.68 & 2 \\
\hline Prevent/reduce livestock diseases & 4.76 & 2 & 4.76 & 2 & 4.75 & 1 \\
\hline Using consultant service or consultant extension workers & 4.6 & 3 & 4.64 & 3 & 4.54 & 3 \\
\hline Liquidity-Keep cash in hand & 4.24 & 4 & 4.17 & 4 & 4.35 & 4 \\
\hline Off-farm work & 4.14 & 5 & 4.14 & 5 & 4.15 & 5 \\
\hline Collecting information & 3.7 & 6 & 3.77 & 7 & 3.60 & 6 \\
\hline Joining extension training program & 3.63 & 7 & 3.85 & 6 & 3.30 & 8 \\
\hline Shared ownership of equipment, joint operations & 3.53 & 8 & 3.67 & 8 & 3.32 & 7 \\
\hline Keeping fixed costs low-rent machinery rather than purchase it & 3.05 & 9 & 3.14 & 9 & 2.92 & 11 \\
\hline Joining farmers corporation & 2.99 & 10 & 2.88 & 10 & 3.14 & 9 \\
\hline Production contracts & 2.83 & 11 & 2.72 & 11 & 2.98 & 10 \\
\hline Asset flexibility-farm building with multiple use & 2.68 & 12 & 2.72 & 12 & 2.63 & 13 \\
\hline Risk reducing technology & 2.63 & 13 & 2.45 & 13 & 2.88 & 12 \\
\hline buying agricultural insurance & 2.06 & 14 & 2.09 & 14 & 2.01 & 14 \\
\hline Kill the cows or sell the cows, quit the business & 1.54 & 15 & 1.45 & 15 & 1.57 & 15 \\
\hline
\end{tabular}

Source: self-calculation based on survey 2010

Note: the order of the risk management is based on the mean score of each one (Column 2).

China is not good enough, and it also makes mastitis become a big problem to Chinese dairy farmers. Meanwhile because of this kind of disease, much antibiotic is used in China, and it caused the antibiotic residue happened more often than developed countries.

The Table 5 shows the varimax rotated factor loadings for source of risk. Before starting PCA, sampling adequacy was checked to detect if the data will factor well. In SPSS, sampling adequacy is measured by Kaiser-Meyer-Olkin criterion (KMO). KMO varies from 0 to 1 and the overall KMO should be 0.5 or higher to precede PCA. With KMO higher than 0.5 is considered as an acceptable condition (Chow 2004). The KMO value of source of risk is 0.517 and is acceptable for PCA. The number of risk was reduced by applying PCA. This resulted in seven factors with eigenvalues greater than 1 and total accounted for $77 \%$ (which can-in social sciences-be regarded as satisfactory; Hair et al. 1995).

Table 5 shows the factor loadings for the source of risks. According to the loadings, the factors can be described as 'production risk', 'institutional risk', 'animal disease', 'input market risk', 'milk contamination risk', 'personal risk' and 'output market risk' respectively.

On the first factor 'production risk', high loading goes to input especially feed variability and some changes in farm operating input. However, those risk from outside of the farm business such as the fire damage, flood damage and other food safety issues happened show a high negative loading. Related food safety issues happened is also included in production risk. It is also can be considered as some risk outside of dairy business itself, so that the loading is negative but not very high. High loading of govern- ment support policy change and changes in technology are related to the second factor 'institutional risk'. In China, most technology improvements are done by national research institutes. Change in technology is also considered as an institutional risk. Animal diseases such as foot and mouth disease, mastitis and Para tuberculosis, veterinary residue and misuse of veterinary medicine also related to the third factor 'animal disease risk'. However, the government provides the vaccine for the food mouth disease twice a year for farmer for free, so that the mouth and foot disease shows a high negative loading. But on the other hand, mastitis and para tuberculosis are not included in the government free vaccine program. Feed price such as corn and other crop price show a high loading and contributes to fourth factor of 'input market risk'. The factor 'milk contamination risk' mainly explains the situation in Hebei Province. The factor 'personal risk' is likely to reflect changes in the farm family, only health problems among household members shows a high loading in this factor. And the milk price variability and change in consumers' preference are related to the last factor 'output market risk'. Consumers' preference change refers to the situation such as consumers would consume more soybean milk instead of milk. However, milk yield is negatively related to milk price, so it shows a negative sign in this factor.

\section{Farmers' risk management strategies}

Producing at the lowest cost and prevents or reduces livestock diseases are considered as the most useful risk management strategies in both Inner Mongolia and Hebei Province (Table 6). However, some strategies such as products contract, farmer 
Table 7 Varimax rotated factor loadings for risk management strategies

\begin{tabular}{|c|c|c|c|c|c|c|}
\hline \multirow[b]{2}{*}{ Category } & \multicolumn{6}{|c|}{ Component } \\
\hline & $\begin{array}{c}\text { Factor } 1 \\
\text { Cost decrease }\end{array}$ & $\begin{array}{c}\text { Factor } 2 \\
\text { Income stabilization }\end{array}$ & $\begin{array}{c}\text { Factor } 3 \\
\text { Income increase }\end{array}$ & $\begin{array}{c}\text { Factor } 4 \\
\text { Farmer group }\end{array}$ & $\begin{array}{l}\text { Factor } 5 \\
\text { Insurance }\end{array}$ & $\begin{array}{r}\text { Factor } 6 \\
\text { Consultancy }\end{array}$ \\
\hline Shared ownership of equipment, joint operations & .843 & .086 & .056 & -.145 & .223 & -.100 \\
\hline Asset flexibility-farm building with multiple use & .815 & -.143 & -.019 & -.008 & -.057 & .116 \\
\hline Risk reducing technology & -.719 & .210 & -.189 & .320 & .108 & -.208 \\
\hline $\begin{array}{l}\text { Keeping fixed costs low-rent machinery rather than } \\
\text { purchase it }\end{array}$ & .582 & .462 & .588 & -.010 & .055 & .080 \\
\hline Production contracts & .005 & .893 & .008 & .028 & -.115 & -.084 \\
\hline Liquidity-Keep cash in hand & -.211 & .816 & -.218 & .326 & -.044 & .127 \\
\hline Off-farm work & -.024 & -.070 & .909 & .074 & -.055 & -.039 \\
\hline Collecting information & .443 & -.254 & .641 & .039 & .156 & .283 \\
\hline Joining the farmers corporation & -.069 & .058 & .011 & .937 & -.004 & -.082 \\
\hline Prevent/reduce livestock diseases & .119 & -.155 & .211 & .065 & .814 & -.195 \\
\hline Buying agricultural insurance & -.041 & .017 & -.210 & -.106 & .729 & .205 \\
\hline Using consultant service or consultant extension workers & .439 & -.216 & -.089 & .005 & -.009 & .778 \\
\hline Joining extension training & .430 & -.468 & -.216 & -.016 & .092 & -.665 \\
\hline Kill the cows or sell the cows, quit the business & .156 & -.467 & -.189 & .190 & -.071 & -.684 \\
\hline Produce at the lowest cost & .464 & -.156 & -.477 & .096 & .365 & .141 \\
\hline Cumulative percent of the variance explained (\%) & 27.622 & 43.917 & 56.236 & 65.842 & 73.529 & 80.429 \\
\hline
\end{tabular}

Source: self-calculation based on survey 2010

Extraction Method: Principal Component Analysis. Rotation Method: Varimax with Kaiser Normalization. Loadings of larger than $|0.5|$ are in bold.

corporation group and agricultural insurance which are viewed as very important in other countries were not popular in China at all, since most dairy farmers in China are still separated and smallscale. In USA, Patrick and Musser (1997) showed that the largescale US farmers viewed liability insurance as important managerial responses to risk. And the 1996 USDA survey found that keeping cash on hand was the chief risk management strategy for every farm size, for every commodity specialty. This result also be proved in the current research and shows that in China, farmers also consider keep cash in hand is a way to deal with all kind of risk. Quit the business is listed as the last thing the farmers would do, and it indicates that the farmers would not easily to give up this business when they meet any risk.

As with the sources of risk, the number of risk management strategies was also reduced by applying PCA. The KMO value of risk management strategies is 0.512 , and is acceptable for PCA. Table 7 shows the varimax rotated factor loadings for risk management strategies. The resulted in 6 factors with eigenvalues greater than 1 and total variance explained of $80 \%$ and is also considered as satisfactory in social science. Based on the concentration of factor loadings, the 6 factors can be described as 'cost decrease', 'income stabilization', 'income increase', 'farmer group', 'insurance' and 'consultancy', respectively.

Controlling fixed costs through shared ownership of equipment and partnership loads high on Factor 1 which is 'cost decrease'. However, compared with others, risk reducing technology is outside of the farm business itself, so that it shows a negative loading in this factor. Usually improvement of technology depends on the government policy and is done by the national institutes. Factor 2 and factor 3 are related to farmers' income. Factor 2, 'income stabilization', has a high loading of product contract which makes a certain income from the farm business itself. Factor 3, 'income increase', has a high loading of off-farm work which keep a certain income out of current farm business. Factor 4 is named as 'farmer group', only one component is included in this factor. It has a high loading of joining farmers' corporation associations. Factor 5, 'insurance', has high loadings of purchasing agricultural insurance. Besides, prevent or reduce animal disease shows a high loading on this component as well. We believe by using proper treatment and animal health checkup can reduce the possibility of animal disease, and it can be viewed as a kind of insurance to farmers. Factor 6, 'consultancy', has high loadings of consultant service and extension training in many aspects.

\section{Conclusions}

Based on above results, we found that risks in dairy farm are categorized as 'production risk', 'institutional risk', 'animal disease', 'input market risk', 'milk contamination risk', 'personal risk' and 'output market risk'. Among these risks, price risk and the animal diseases risk are the most serious in dairy farmers' perception as a single risk which causes major troubles to them.

Risk management strategies are categorized as 'cost decrease', 'income stabilization', 'income increase', 'farmer group', 'insur- 
ance' and 'consultancy'. Among these strategies, dairy farmers feel that producing at the lowest cost and prevents livestock disease are the most effective risk management strategies as a single strategy. Dairy farmers in China largely rely on extension service or veterinary, so that to develop the veterinary extension service and to guide farmers to avoid livestock disease is a good way to reduce these related risks. Extension service and veterinary are good example of 'consultancy'.

Farmer group and agricultural insurance becomes a way to help farmers to manage risk in crops and some other animal products; however, it is not widely accepted by dairy farmers. Promotion of these strategies might be useful for dairy farmers as well and might help them to avoid many risks and reduce losses.

For the government, more consultant services should be offered; some new risk management strategies should be extended to farmers such as production contract. For dairy farmers, new risk management strategies such as agricultural insurance should be more accepted. The milk powder scandal in China happened in 2008 made negative effect on local milk industry (mainly refers to Hebei Province). It totally destroyed the local business and public trust from all over the nation. From that point, two years already have been past, farmers have difficulty to sell their milk even now. A set of effective risk management strategies for dairy farmer is needed.

\section{References}

Abdi, H. and L. J. Williams (2010) Principal Component Analysis, Interdisciplinary Reviews: Computational Statistics, 2.4: 433-459.

Chen, Z. (2009) Research on Quality and Safety Control of Dairy Products in China, Thesis of Master Degree, Yangzhou University of China (in Chinese).

Chow, W. (2004) An Exploratory Study of the Success Factors for Extranet Adoption in E-supply Chain, Journal of Global Information Management, 12.1: 60-67.

Economic Research Service (ERS), USDA (1997) Agricultural Economic Report No. 774, Managing Risk in Farming: Concepts, Research, and Analysis, available at <http://www.nal.usda.gov/ref/USDApubs/aer.htm $>$.

Flaten, O., G. Lien, M. Koesling, P. S. Valle and M. Ebbesvik (2005) Comparing Risk Perceptions and Risk Management in Organic and Conventional Dairy Farming: Empirical Results from Norway, Livestock Production Science, 95: 11-25.

Fleisher, B. (1990) “Agricultural Risk Management”, Lynne Rienner Publishers Inc., USA.

Food Agriculture Organization of United Nations (FAO) (2008) FAOSTAT Agriculture Database, accessed November 2008, available at $<$ http://faostat.fao.org/site/339/default.aspx $>$.

Hair, J. F., R. E. Anderson, R. L. Tatham and W. C. Blac (1995) "Multivariate Data Analysis", Macmillan Publishing Company, New York.

Lindsay, I. S. (2002) A tutorial on Principal Components Analysis, available at $<$ http://kybele.psych.cornell.edu/ edelman/Psych-465 Spring-2003/ PCA-tutorial>.

Martin, S. (1996) Risk Management Strategies in New Zealand Agriculture and Horticulture, Review of Market and Agricultural Economics, 64: 31-44.

Meuwissen, M. P. M., R. B. M. Huirne and J. B. Hardaker (2001) Risk and Risk Management: An Empirical Analysis of Dutch Livestock Farmers, Livestock Production Science, 69: 43-53.

Nanseki, T. (2011) "Management of Risk and Information in Agriculture", Agriculture and Forestry Statistics Publishing Inc., Japan (in Japanese).

Patrick, G. F. and W. N. Musser (1997) Sources of and responses to risk: factor analysis of large-scale US corn-belt farmers, ed. OECD (2000) "Income risk management in agriculture", France: OECD: 45-53.

SPSS Inc. (2007) "SPSS Base 15.0 for Windows User's Guide”, SPSS Inc., Chicago IL.

Wilson, P. N., T. R. Luginsland and D. V. Armstrong (1988) Risk Perceptions and Management Responses of Arizona Dairy Producers. Journal of Dairy Science, 71: 545-551.

Wu, Y. (2009) The research on Inner Mongolia Dairy Risk Factor, Thesis of Master Degree, the Inner Mongolia Agriculture University of China (in Chinese).

Received April 26, 2011

Accepted January 23, 2012

Management \& Economics 